\title{
Culture and City Branding: Mega-Events and Iconic Buildings as Fragile Means to Brand the City
}

\author{
Müge Riza \\ Eastern Mediterranean University, Famagusta, North Cyprus \\ Email: muge.riza@gmail.com \\ Received 16 June 2015; accepted 21 July 2015; published 24 July 2015 \\ Copyright (C) 2015 by author and Scientific Research Publishing Inc. \\ This work is licensed under the Creative Commons Attribution International License (CC BY). \\ http://creativecommons.org/licenses/by/4.0/ \\ c. (i) Open Access
}

\begin{abstract}
In the last years many cities investigated diverse approaches to attract more audience and stimulate their economy. One of the key terms in this context is city branding. City branding strategies are used as a tool to race with other cities by displaying appealing images of the city and its assets. In this context, culture is as a marketable strength and new opportunity for cities to increasingly gain popularity. This paper deals with the utilization of cultural as a branding device. It discusses the role of culture in city branding and compares the use of recent popular tools, namely largescale events, festivals and iconic architecture as a means for branding purpose. Finally, the paper argues that iconic buildings and mega-events using permanent structures in contrast to smaller events and festivals are unsustainable means to promote the culture of the city, as most of the time they are undermining the existing local culture in favour of a global taste, broadcasting similar images and activities.
\end{abstract}

\section{Keywords}

City Branding, Culture, Iconic Architecture, Mega-Events

\section{Introduction}

Countries and increasingly cities are challenged with globalization and its effects on their international reputation. The fear of economic drawbacks has resulted in a strong competition between cities and nations [1]. Citizens and visitors seem to be enthusiastic about new images, extraordinary buildings and exciting places to live and visit. Additionally, investors chose locations for their business with appealing environment and cultural and social facilities. As a consequence, local governments have started to consider city branding as part of their ur- 
ban management scheme to attract a broader market [2] [3]. As argued by Lang, a city has to act as a "business company" selling and promoting its goods. However, branding is far more than creating and selling appealing images. It is about the creation of authentic metaphors. Literature reveals that especially culture has developed as a strong "good", which plays a substantial role in city branding [4] [5]. As accurately mentioned by Kavaratzis, "Culture provides consumable experiences; culture acts as a source for economic activity; culture attracts the creative class; culture attracts tourists..." [6]. The research questions are as follows: how culture is used in city branding? Which cultural is going to be branded? Is iconic architecture representing local (material) culture? The aim of this paper is to develop answers to these questions by exploring the role of material culture in city branding. The article deals with the relationship between city branding and culture. Different approaches on how city branding is utilized through the use of culture will be introduced with a focus on events and iconic structures. Finally, large-scale events and iconic architecture as a controversial tool in city branding are discussed. The paper claims that iconic buildings and mega events using iconic structures are not representing authentic cultural values and leading to similar city images or activities. In this sense this paper tries to evoke question marks about the uncritical usage of these strategies for branding purposes and their sustainability in a long term.

\section{City, Culture and City Branding}

The city has always been a symbol for culture and cultural activity as it is providing more than the basic needs of existence such as shelter and food. Even for the ancient Greeks the city was a synonym for civilized life [7]. As defined by Wells, culture of the city are "those things that make the city distinct from other human settlements there are things in cities that, in general, it is difficult to imagine having in a place outside of the city". Furthermore he argues, that cities themselves might be characterized as cultural artefacts as well [8]. In cities, as mentioned by Zukin, culture is present through the built environment in form of palaces, theatres, museums and temples, and also through parks, marketplaces and memorials [9]. Hence, most cities own a variety of cultural assets that are possible features to utilize for branding purposes. In this sense not only heritage buildings and history are targeted, but other cultural assets are considered as well to develop a strategy to promote the city. As summarized accurately by Ashworth, there are mainly three instruments used by city authorities to increase the worldwide attention of the city: event hall marketing, personality association and flagship and signature district [10]. In the recent agenda of cities, especially two of these strategies are used effectively as branding devices: large-scale/mega events such as European Capital of Culture or the Olympic Games, and iconic architecture [1]. As argued also by Kong, cities with global ambitions have realized "the need to accumulate cultural capital, for which one means is to create new urban spaces, in particular, new cultural urban spaces (e.g. grand theatres, museums, libraries)" [11]. No doubt, in the current worldwide trend of globalisation, cities are in need to get attention as they are bound to and influenced by the global economy and development. However, it is worth to critically examine the usage of these kinds of approaches as a branding tool as there is a danger of reproducing similar images and spectacles around the world without considering the authenticity of the local culture. Therefore, in the upcoming part small scale events will be compared with large-scale events and iconic architecture under their contribution to express and integrate local culture.

\section{Small Events versus Mega-Events and Iconic Architecture}

In general, events could be characterized through their exclusivity as well as through their temporary presence. Events are designed mainly for a short period in which the city is transformed into a "cultural stage". Especially smaller scale events are attractive as they create a positive image of the city and give opportunities to experience the city as a participant. Additionally, if they are offered continually during a specific period of the year, they might be considered as a tool to gain attention and recognition. The below shown example is a street festival in one of the most popular high streets in Munich, Germany, the Leopoldstrasse (Figure 1). The event is held regularly two times each year and gained popularity for tourists as well as for local visitors. One advantage of these kinds of events is that they are adaptable to the needs of the visitors and are able to handle with changes in the cultural agenda. As they are not manifested through "buildings", they are only temporary transforming or influencing the existing setting - in terms of spatial, visual as well as social conditions (Figure 2).

Large-scale events such as The European Cultural Capital or the Olympic Games have similar roots as smallscale events. They are planned as temporary actions, with the aim to host visitors and participants for a limited period during the year. Indeed, cities could gain positive reputation of such events. For most European Cities the nomination as a "European Cultural Capital" is a prestigious position. To be a cultural capital means to get financial 


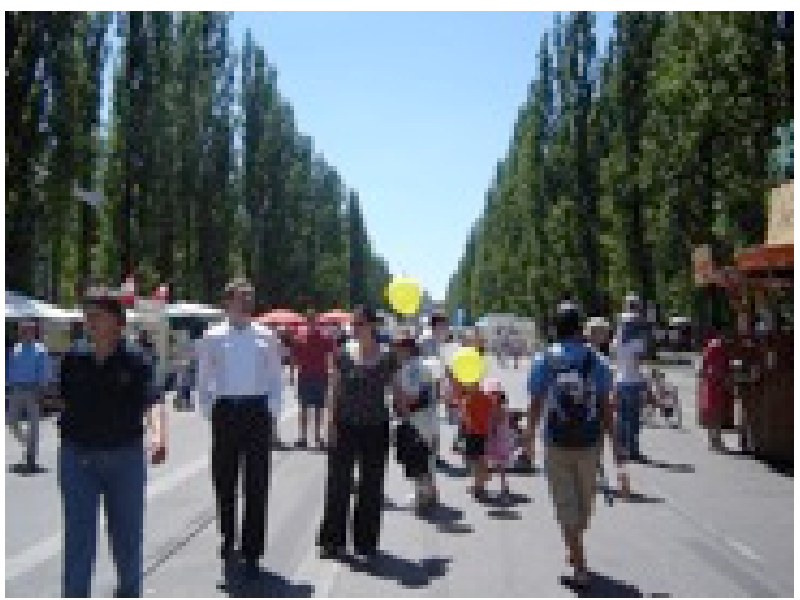

Figure 1. Street festival on a main street in Munich, Germany (pictures: personal archive).

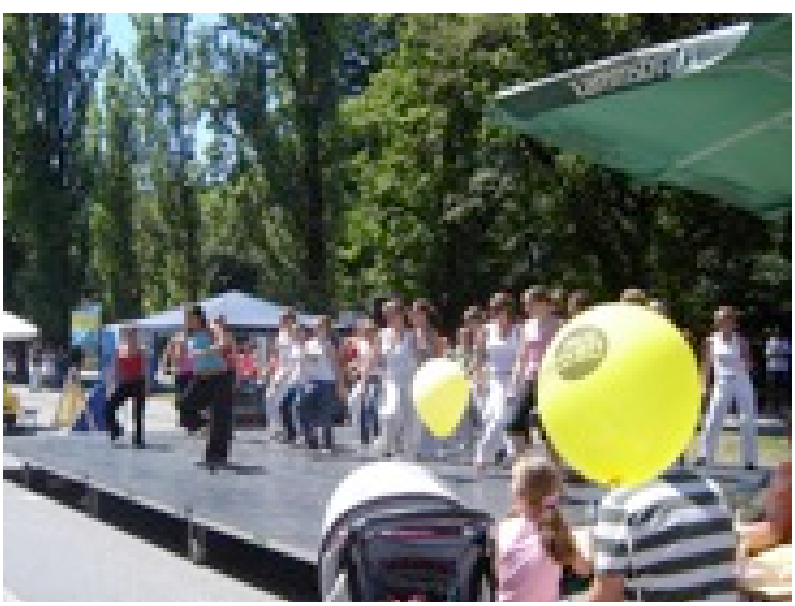

Figure 2. Temporary stage pictures: personal archive.

support for cultural activities, development of image and international audience and recognition [5]. In a wider perspective, it appears as if there are reasonable arguments for large events as they provide a variety of benefits for the host city, economic as well as cultural. Problematic are those cases, where the promotion of the cultural event is done at the expanse of the local cultural environment [5]. Unfortunately, in many cases those kinds of events are in contrast to smaller festivals accompanied by several "fixed" means to promote the festivals and events. Zhang and Zhao, in their research of the Olympic Games in Beijing, were exploring the branding of Beijing through the Olympic Games in 2008. According to them Beijing's "identities were branded symbolically through the logo, the theme slogans, the mascots and the like, and materially through construction of landmark buildings and infrastructure”. In order to host the athletes the National Stadium was constructed in form of an iconic architectural design, while traditional neighbourhoods were removed [12]. Hence, the construction of the iconic building destroyed existing texture and local culture. In the case of Beijing this approach was disastrous for the residents of the area and generated damage to cultural continuity and identity. As argued above, events do not bear significant harm as long as they are temporary and not presented through architectural manifestation. Instead buildings, ones constructed, will be present in the built environment, as a consistent part of it. The same argument is valid for iconic structures that are not constructed as part of a cultural mega-event. Often city authorities assume that impressive architecture by default is increasing attractiveness and reputation of the city. In fact, this could be the case as long the iconic building is actually unique and identifiable. Unfortunately, cities are seeking for extraordinary architecture, but getting into the trap of exposing similar city images (Figure 3 and Figure 4). Fitting examples for this case are the Guggenheim Museum in Bilbao and the Walt Disney Concert 


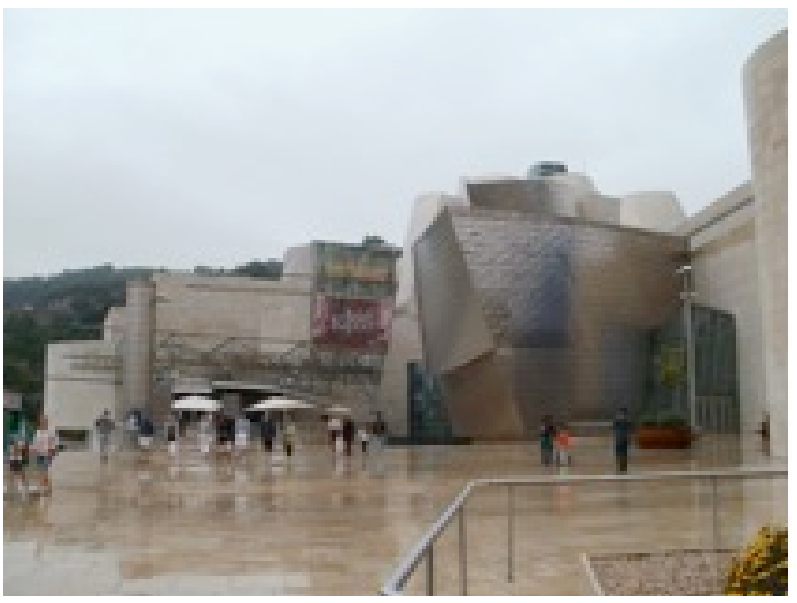

Figure 3. Guggenheim museum in Bilbao (picture: personal archive).

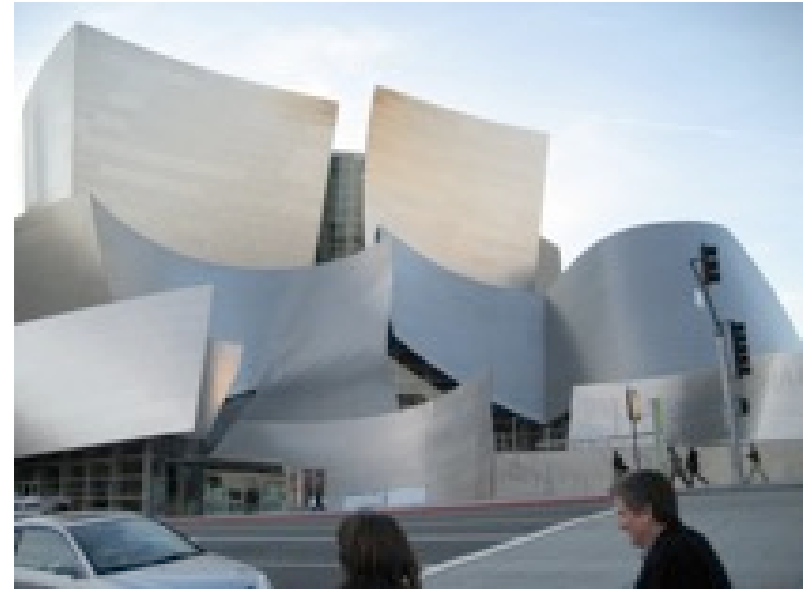

Figure 4. Walt Disney Music Hall in Los Angeles (picture: personal archive).

Hall in Los Angeles, both designed by Frank O’Ghery. Although, the buildings were established in different locations and for different purposes, the similarities in terms of form and used material are apparent. As a result the context to the surrounding and to the culture is disregarded, as it is not possible to distinguish neither their location nor their function from their outer appearance. The comparison of the two buildings shows that because of their similarities the context to the urban setting is replaced by the context to the architect. Even more, Bandarin argues that architects are "looking to the wrong direction: inwards themselves, not outwards to the urban contexts in which they are building” [13].

Accordingly, in most cases contemporary iconic architecture is not representing or referring to local culture and authenticity. As argued by several researchers, even though the world is getting closer and more mobile, as an effect of globalization local identity is becoming an important issue for cities [5] [14]. Evans assume, that every city has a "certain cultural character", which makes it irreplaceable and different from other places [15]. Additionally, as argued by Lui, places are carrying meanings, history and local specifications, while especially the "local", and its place-based character, makes it unique [16]. Unfortunately, locality is currently undervalued in many city branding practices and city authorities should pay more attention to the cities exclusiveness rather than to global images. When using iconic structures for branding purposes, it should be noted that a brand itself is a symbol that identifies and ads value. As many cities posses similar characteristics, a city branding strategy have to deal with the specific values of the city to distinguish it [12]. The sole repetition of similar images will lead to loss of (existing) identity and decreases finally the brand value [17]. Therefore any successful city branding has to consider its own local values and cultural peculiarities to establish a sustainable and authentic city brand image. As argued by Evans the "commercial and competitive" city branding is able to create irregular 
and unexpected outcomes [15]. Therefore it is uncertain how the city will be affected in long term through the use of mega cultural projects including iconic buildings, as they tend to "reinforce a homogenous culture" [15]. More than this, Lui argues that places are not just a site for the installation of world-class facilities and "signature architecture". A place is required to develop its own sense of place, a quality of permanence [16]. Iconic buildings can go anywhere in the world. On the other hand, it should be considered that the "sense of place" is mainly visible in the core of historic cities where the texture is still old, whereas in the new areas of the cities the "sense of place" does not occur in the same presence [18]. Therefore it is important to distinguish in which part of the city the iconic architecture is going to be assembled.

\section{Conclusion}

It is outlined in this paper that city branding through culture is a complex and controversial approach. Especially the use of materialized culture in form of mega events and iconic structures to promote the culture of a city may be accompanied by unpredictable risks. An iconic building, successful in getting attention for a specific purpose in a specific place, will be repeated in other locations regardless of the existing background. In such cases the culture of the local vicinity is not considered or even ignored. Contextual qualities, cultural and local issues are put into the background in favour of global representations. As a consequence all over the world we are facing the trend towards unified city images and similar public spaces. As branding is about the creation of authentic and distinct images, construction of similar images would end up in most cases in short lasting success. Ignoring the local culture in advance of appealing "global images" would finally end up in the creation of same city images, which at the end would not articulate any local culture. That in turn would affect cities in a long term negatively as they could lose their authenticity, which is essential for successful city branding. City governors should be aware of the qualities and values of their city and choose a branding device that fits particularly to their case. Otherwise city images would be interchangeable and the place would lose attractiveness for tourists and visitors. Likewise locals can feel themselves alien with the building or events that are not representing their culture and habits.

\section{References}

[1] Kavaratzis, M. (2005) Branding the City through Culture and Entertainement. The AESOP 2005 Conference, Vienna, 13-18 July 2005.

[2] Salo, L. (2012) Building a Creative City Brand through an International Mega-Event. Case: World Design Capital Helsinki 2012. Master Thesis, Turku School of Economics, Turku.

[3] Eshuis, J. and Edelenbos, J. (2009) Branding in Urban Regeneration. Journal of Urban Regeneration and Renewal, 2 , 272-282.

[4] Hornskov, S.B. (2007) On the Management of Authenticity: Culture in the Place Branding of Oresund. Place Branding and Public Diplomacy, 3, 317-331. http://dx.doi.org/10.1057/palgrave.pb.6000074

[5] Kunzmann, K.R. (2004) Culture, Creativity and Spatial Planning. Town Planning Review, 75, 383-404. http://dx.doi.org/10.3828/tpr.75.4.2

[6] (Kavaratzis, M. and Ashworth, G. (2015) Hijacking Culture: The Disconnection between Place Culture and Place Brands. Town Planning Review, 86, 155-176. http://dx.doi.org/10.3828/tpr.2015.10

[7] Short, J.R. (1996) The Urban Order. An Introduction to Cities, Culture and Power. Blackwell Publishers, Cambridge.

[8] Wells, K. ( 2007) The Material and Visual Cultures of Cities. Space and Culture, 10, 136-144. http://dx.doi.org/10.1177/1206331206298544

[9] Zukin, S. (2004) Dialogue on Urban Cultures: Globalistaion and Culture in an Urbanizing World. UN-Habitat World Urban Forum, Barcelona, 13-17 September 2004.

[10] Ashworth, G.J. (2009) The Instruments of Place Branding: How Is It Done? European Spatial Research and Policy, 16, 9-21. http://dx.doi.org/10.2478/v10105-009-0001-9

[11] Kong, L. (2007) Cultural İcons and Urban Development in Asia: Economic İmperative, National İdentity, and Global City Status. Political Geography, 26, 383-404. http://dx.doi.org/10.1016/j.polgeo.2006.11.007

[12] Zhang, L. and Zhao, S.X. (2009) City Branding and the Olympic Effect: A Case Study of Beijing. Cities, 25, $245-254$. http://dx.doi.org/10.1016/j.cities.2009.05.002

[13] Bandarin, F. (2006) Urban Conservation in an Age of Globalization. http://www.ihbc.org.uk/context archive/97/bandarin/edinburgh.html 
[14] Zukin, S. (1995) The Culture of Cities. Blackwell Publishing, Oxford.

[15] Evans, G. (2003) Hard Branding the Cultural City: From Prado to Prada. International Journal of Urban and Regional Research, 27, 417-440. http://dx.doi.org/10.1111/1468-2427.00455

[16] Lui, T. (2008) City-Branding without Content. Hong Kong’s Aborted West Kowloon Mega-Project, 1998-2006. IDPR, International Development Planning Review, 30, 215-226.

[17] Riza, M., Doratli, N. and Fasli, M. (2012) City Branding and Identity. Procedia-Social and Behavioral Sciences, 35, 293-300. http://dx.doi.org/10.1016/j.sbspro.2012.02.091

[18] Cresswell, T. (2004) Place: A Short Introduction. Blackwell Publishing, Oxford. 